\title{
FEATURE Drainage water management for water quality protection
}

\author{
Jeffrey S. Strock, Peter J.A. Kleinman, Kevin W. King, and Jorge A. Delgado
}

$\mathbf{L}$ and drainage has been central to the development of North America since colonial times, with the first organized drainage efforts occurring as early as the 1600s (Evans et al. 1996). Drainage has been encouraged to improve public highways, reduce public health risks, promote increased crop yield and reduced yield variability, reduce surface runoff and erosion, and increase land value. Agricultural drainage includes artificial subsurface drainage and surface drainage. Most agricultural producers improve the drainage on their land for better trafficability, to enhance field conditions, to facilitate timely planting and harvesting operations, and to help decrease crop damage from saturated soil and standing water during the growing season. Agricultural drainage improvement also decreases year-to-year variability in crop yield, ensuring consistent production.

Increasingly, agricultural drainage is being targeted as a conduit for pollution, particularly nutrient pollution (Needelman et al. 2007). Considerable resistance exists in some regions to the expansion of drainage systems despite their importance to food production, with up to $50 \%$ of the cropland in some states under artificial drainage. However, because drainage ditches and subsurface drainage systems convert diffuse flows from the landscape into concentrated flows, they also provide opportunities for precision conservation, the targeting of specific practices to improve downstream water quality (Delgado and Berry 2008). Drainage water management has emerged with the objective of balancing production and conservation goals. To be effective, drainage water management

Jeffrey S. Strock is an associate professor with the University of Minnesota based in Lamberton, Minnesota. Peter J.A. Kleinman is a soil scientist with the USDA Agricultural Research Service in University Park, Pennsylvania. Kevin W. King is an agricultural engineer with the USDA Agricultural Research Service in Columbus, Ohio. Jorge A. Delgado is a soil scientist with the USDA Agricultural Research Service in Fort Collins, Colorado. strategies must account for the many facets of today's farming systems. Neither one practice alone constitutes drainage water management nor does one strategy fit all systems.

The export of agricultural drainage water and associated pollutants to surface water can be managed and controlled, to an extent, using a combination of infield, edge-of-field, and off-site practices. With all practices, their applicability and performance depends upon the context (physiography, management systems, and pollutants of concern) in which they are to be implemented. We seek to highlight major areas within drainage water management that show promise from the standpoint of water quality protection, emphasizing the array of options, established and nascent. What follows are eight components of drainage water management where land managers can positively impact water quality. Our intent is not to prescribe a strict set of practices, but rather to showcase areas within drainage water management that provide opportunities for water quality protection and enhancement.

\section{DRAINAGE SYSTEM DESIGN}

As older drainage systems are updated or replaced, and as new land is drained, the first opportunity to improve management is at the design phase. Factors influencing drainage design include soil drainage characteristics (i.e., dynamics and extent of saturation), cost (installation, maintenance), field management (e.g., tillage, crop, and nutrient management), existing drainage infrastructure (type of pipe, existing line spacing, depth, and location of outlets), and environmental concerns (e.g., habitat, watershed impairments). The two design variables most directly tied to pollutant export are drainage intensity and drainage placement.

Drain intensity (depth and drain spacing) determines whether a drainage network is capable of reducing the depth of a water table between the drain lines to an elevation most beneficial to plant growth within 24 to 48 hours after a rain. Typical drain depths range from 0.6 to $1.5 \mathrm{~m} \mathrm{(2} \mathrm{to}$ $5 \mathrm{ft}$ ), while spacing ranges from 10 to 100 $\mathrm{m}$ (33 to $328 \mathrm{ft}$ ). Drainage intensity plays a determinative role in pollutant loads, as pollutant losses are primarily influenced by the volume of water drained. Deeper, more dense designs possess a greater transport potential than shallower less dense systems. For instance, in Minnesota, Sands et al. (2008) found that shallow drain pipe installation and drainage systems designed for a lower drainage intensity resulted in less water drainage and less nitrate-nitrogen loss compared to deeper drains or greater drainage intensity. Likewise, in Indiana, Kladivko et al. (1991) found that progressively narrower drain spacing yielded more nitrate-nitrogen loss. Therefore, to protect water quality, drainage intensities should be designed to provide adequate drainage for realistic site use expectations, avoiding historical intensities that often resulted in excess drainage.

Decisions on where to site drainage management systems on a farm or within a field traditionally emphasized agronomic factors, without considering water quality variables. However, the emergence of critical source area management for water quality protection, i.e., the targeting of remedial practices to areas where a pollutant source and a process to mobilize that pollutant overlap, provides an opportunity for water quality factors to be included in the siting process. Because drainage systems directly connect sources of pollution in the landscape to receiving waters, source avoidance must be considered in drainage system design. For instance, a field with high soil phosphorus content and therefore high potential to desorb dissolved phosphorus to drainage water can become a critical source area of phosphorus export if it is drained. Use of simple site assessment tools (Phosphorus Index, Nitrogen Leaching Index) can aid in the determination of whether installation of artificial drainage will convert a site into a critical source of water quality concern (Sharpley et al. 2003; Delgado et al. 2008). 


\section{CONTROLLED DRAINAGE}

Controlled drainage has received considerable attention in recent years (Nistor and Lowenberg-DeBoer 2007), with national and regional initiatives aimed at expanding its adoption (e.g., Agricultural Drainage Management Task Force). Controlled drainage may be installed on subsurface drains as well as open ditches, allowing the water table to be adjusted at any level between the ground surface and the drainage depth to prevent excess drainage (figure 1). Ideally, controlled drainage promotes moisture storage during periods when drainage is not necessary. Excess and deficit soil-water conditions in the soil profile can be managed to provide better plant growth conditions for crop production. Through the implementation of proper management practices and strategies, an array of water quality benefits has also been documented. However, water quality trade-offs must be considered, as controlled drainage has the potential to increase overland flow from drained lands (Riley et al. 2009), and there remains some questions as to the fate of the nitrogen conserved with this practice. Several hypotheses concerning the fate of nitrogen in controlled drainage systems have been identified but have not been adequately investigated, including deep percolation, deep percolation and subsequent denitrification, and increased crop use efficiency.

Substantial work exists documenting the merits of controlled drainage under different conditions. Seminal research in North Carolina showed that controlled drainage was capable of reducing drainage volume and nitrate-nitrogen loss by $40 \%$ to $50 \%$ compared to conventional free drainage (Skaggs et al. 2005). Phosphorus losses were decreased by $25 \%$ to $35 \%$. These general findings have been confirmed elsewhere (Lalonde et al. 1996; Tan et al. 1998; Feser et al. 2010), resulting in the generalization that a properly sited and managed controlled drainage system can lower discharges and pollutant loads by roughly $30 \%$ compared to free drainage systems. The benefit of controlled drainage on crop yields has generally been modest and highly dependent on management and soil conditions. Several studies suggest that crop yields from controlled drainage

\section{Figure 1}

Schematic of in-field water level control structure used in controlling drainage from an in-field tile system. Controlled drainage may also be adapted to open drainage ditches.

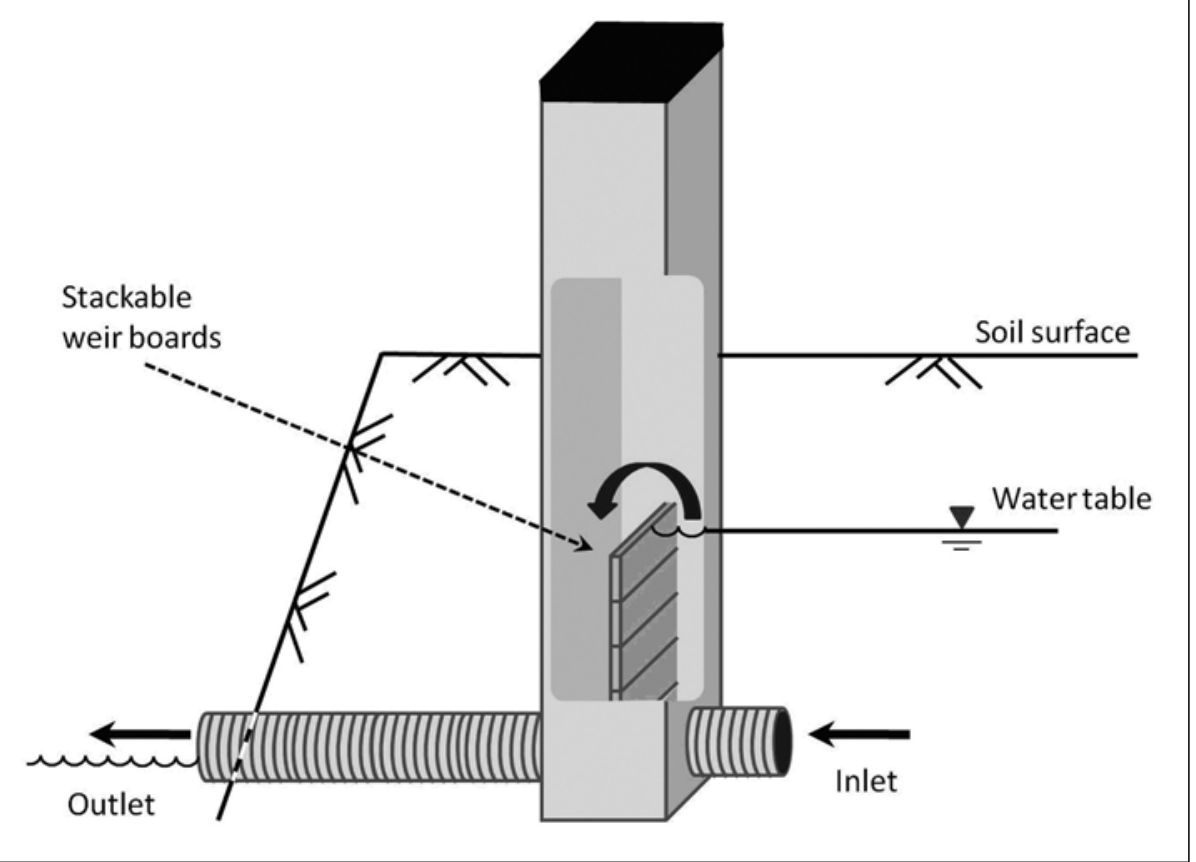

systems may surpass those from conventional or free drainage systems by $5 \%$ to 10\% (Skaggs et al. 2005; Madramootoo et al. 2007).

Opportunities for controlled drainage are widespread, but adoption remains limited in many areas of the United States. Key concerns hampering adoption derive from uncertainty over return on investment (Madramootoo et al. 2007), potentially adverse impacts on crop establishment and growth, and system maintenance. Retrofitting existing drainage networks to accommodate flow control systems is dependent on current design and, in the case of tile drains, age or type of pipe. In theory, all existing systems could be retrofitted with a control structure; however, the zone of influence would be limited by the current design and topography. Drainage water management requires a design that not only takes advantage of topography but also considers how topography will affect the extent to which drainage control impacts the landscape. Generally, controlled drainage is most cost-effective in flatter landscapes where a single structure can influence a greater area; however, the advent of new technologies extends opportunities for controlled drainage to be implemented on sloping landscapes where subsurface drainage may be necessary.

DRAINAGE DITCH MANAGEMENT

Open drainage ditches range widely in their characteristics and thus in the opportunities that they provide for water quality protection. In some cases, low order streams have been channelized and straightened (ditched) or new channels constructed to promote field drainage. In areas with slowly permeable soils, vegetated open ditches typically act as conveyance systems for in-field subsurface drainage systems. In other areas with permeable soils and high regional water tables, in-field drainage is achieved using open ditches. During low flow conditions, ditches function like a linear wetland, biologically and physically, with relatively long hydraulic residence times. However, during wet periods, ditches function more like fluvial, transport-dominated systems. Unlike fluvial systems, regular ditch maintenance activities disrupt natural channel forming processes and successionary wetland communities.

Considerable research documents the role of drainage ditches as conduits of field pollutants (e.g., Kleinman et al. 2007) and 
the effect of routine ditch maintenance practices such as dredging in disrupting the natural buffering ability of ditches (Smith and Pappas 2007; Pappas and Smith 2007; Shigaki et al. 2008). However, a growing body of research suggests the potential exists for using vegetated open ditches as best management practices for mitigating potential agricultural contaminants. In a paired ditch study, Strock et al. (2007) utilized a water level control structure to restrict flow and alter the water table height of an open ditch. Increasing the retention time of water within the ditch promoted sedimentation within the ditch channel and decreased nitrate-nitrogen and total phosphorus export compared to a noncontrolled ditch. One concern with using a water level control structure in ditches is that the level of water storage in the ditch could negatively impact drainage outflow from field tile systems. This perceived problem may be remedied by installing multiple low-level retention structures along long ditch reaches.

The basic trapezoidal design of the drainage ditches has been questioned in Ohio, where researchers have adapted key characteristics of natural channel systems into drainage ditch design (figure $2)$. The two-stage ditch, which includes a low-flow channel as well as a floodplain area, improves bank stability, lowers the erosivity of ditch flows, and increases sediment storage capacity (Powell et al. 2007). This design lowers maintenance costs (dredging, bank stabilization) and is expected to lessen downstream yields of sediment. Initial excavation costs of twostage ditches are greater than excavation costs of conventional ditches because two-stage ditches are generally 3 to $6 \mathrm{~m}$ $(10$ to $20 \mathrm{ft})$ wider, resulting in the loss of 0.4 to 1.2 ha ( 1 to $3 \mathrm{ac}$ ) of land per linear mile of two-stage ditch. An additional concern with two-stage ditches is that they increase flow-handling capacity by $25 \%$ to $100 \%$, potentially increasing downstream flooding.

\section{WETLANDS}

Many drainage management practices seek to mimic or restore some aspect of wetland function to artificial drainage systems. Targeting wetlands (pocket and treatment

\section{Figure 2}

Profiles of conventional drainage ditch with trapezoidal design and two-stage design. The two-stage ditch is designed to mimic natural fluvial processes, providing a floodplain to dissipate the energy of flow when it is elevated as well as storage for sediment.
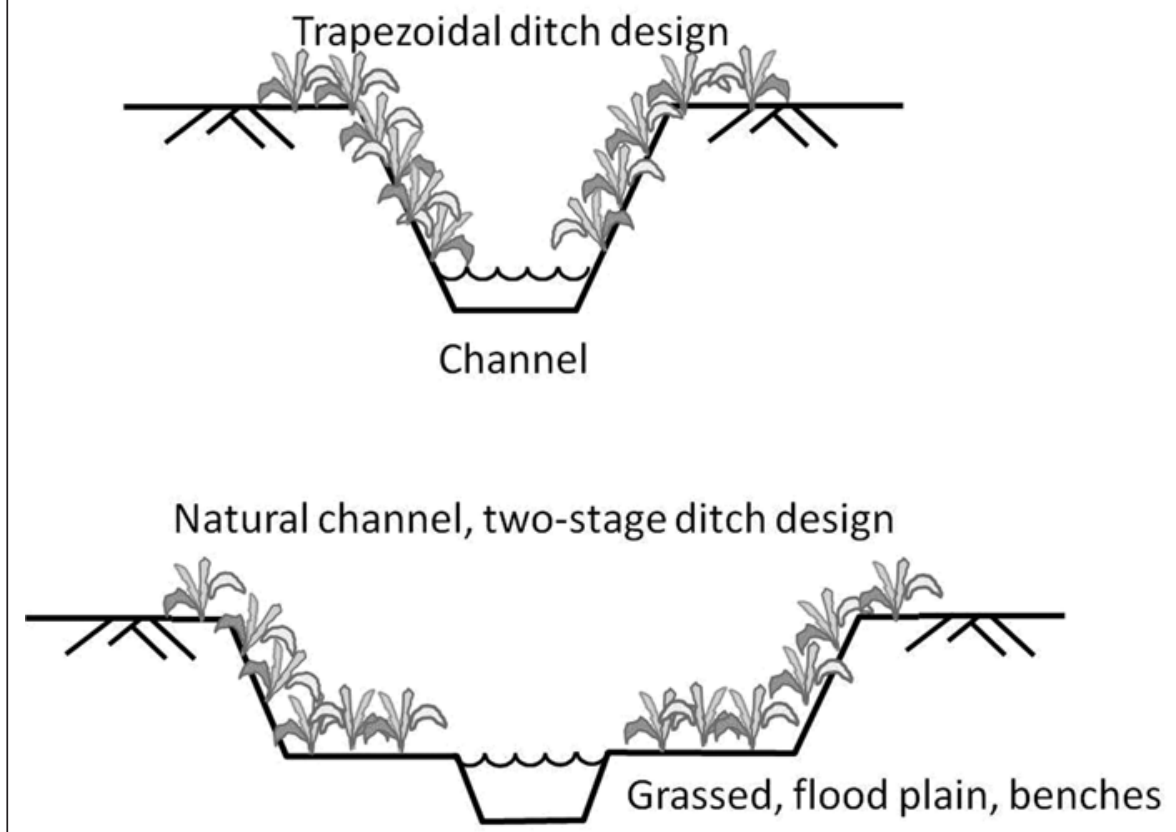

\section{Low flow channel}

wetlands, retention basins) to critical positions along drainage pathways can be an effective means of improving water quality (e.g., Crumpton et al. 2008). Natural, restored, and constructed wetlands have long been employed to handle and treat agricultural drainage, regardless of whether the influent consists of surface water runoff or subsurface drainage. In Iowa, an innovative pilot program (Iowa Drainage and Wetland Landscape System Initiative) integrates in-field nutrient management, drainage system design, and strategically located wetlands to simultaneously reduce nonpoint source pollution and improve on-farm profitability. The combination of practices employed by the program addresses pollutants in both surface and subsurface flow, lowering runoff volume, rate, and peak flow from participating operations, increasing wetland services across the landscape, and even decreasing greenhouse gas emissions.

The effectiveness of wetlands in treating drainage water depends upon a variety of factors, ranging from climate to hydraulic loading and residence time, to contrib- uting area and influent characteristics, to wetland ecological community (Kadlec and Knight 1996; McCarty and Ritchie 2002). In general, optimal reduction in pollutants occurs when hydraulic residence time through a wetland is long and hydraulic loading rate is low. Under the right conditions, wetlands are efficient at promoting sedimentation and at removing influent nitrogen via denitrification. Wetlands can remove dissolved forms of phosphorus from influent, but they are stores, not sinks, of phosphorus. Dissolved phosphorus removal capacity is diminished over time, especially when influent phosphorus loads are high. When wetland soils become saturated with respect to phosphorus, they may actually become sources of effluent phosphorus.

Even volunteer wetlands in drainage systems, e.g., those that can become established in open ditches, can play a significant role in water quality improvement, although they are often, erroneously, considered to be a sign of drainage system decline. Indeed, unnecessary emphasis is often given to practices such as dredging 
of ditches, which destroy entrained wetlands and wetland function, even when hydraulic function is not being adversely impacted by volunteer wetland communities. Real barriers do exist, however, to incorporating wetlands into drainage systems. For instance, construction of wetlands can disrupt the continuity of farming practices as a result of their location, even with the most conscientious targeting process. Perhaps the greatest barrier to the adoption of treatment wetlands is the cost of restoration or construction and lost land.

\section{BUFFERS AND VEGETATIVE FILTER STRIPS}

Numerous studies have quantified the runoff and nutrient reduction potential of vegetated buffers (Osborne and Kovacic 1993; Dosskey 2001; Helmers et al. 2008). The incorporation of buffers and filter strips into drainage systems can serve not only to improve water quality but also to improve effectiveness of drainage systems in the long term. Buffers and filter strips are primarily employed to intercept overland flow and in some cases shallow ground water. Their major function is to reduce the velocity of runoff water through resistance caused by the presence of dense perennial vegetation in the buffer. This reduction in flow velocity may result in increased water infiltration and deposition of suspended solids. The later process not only protects downstream water bodies but can also preserve the integrity and function of drainage systems that are often impacted by sedimentation. In addition to these benefits, buffers have been shown to be zones of assimilation of nutrients and denitrification.

Performance of a vegetative buffer is related to several factors, including the drainage area to buffer area ratio, the characteristics of the precipitation event(s), the condition of the drainage area, the degree to which surface flow is concentrated, and species composition. Buffer designs are described in the USDA Natural Resources Conservation Service Conservation Practice Standards (USDA NRCS 2010) and include such practices as alley cropping, conservation cover, contour buffer strips, riparian herbaceous cover, riparian forest buffers, filter strips, grassed waterways, and vegetative barriers. While the traditional, required width of buffer strips may limit the situations where they may be adopted, considerable evidence suggests that even small, strategically placed buffer strips can be effective in improving certain water quality objectives (e.g., Castelle et al. 1994) and are an improvement over nonadoption.

\section{SIDE-INLET CONTROLS}

Side inlets serve as surface runoff outlets from agricultural land into drainage ditches and are very common wherever surface drainage ditches are present. These side inlets contribute sediment and concomitant nutrients to surface waters in artificially drained agricultural landscapes. Side-inlet controls such as culverts and drop pipes can prevent gully erosion, control the rate of flow to ditches, and create sedimentation areas to improve water quality. Current designs do not consider water quality impacts. Research is in its beginning stages and is needed to quantify the benefits of this practice on suspended solids and nutrient loading to receiving waters and to develop design guidance so that side-inlet controls can be implemented on a widespread basis.

\section{REACTIVE BARRIERS}

Permeable reactive barriers have long been used in groundwater remediation, but their application to drainage waters remains in its nascent, albeit promising, stages. The general concept is to intercept drainage water with materials that remove chemical contaminants. Different materials and different processes are required to treat the two primary nutrients of concern in drainage waters. Reduction curtains and infiltration filters have been proposed to decrease nitrogen loads entering ditches (Jaynes et al. 2008; Greenan et al. 2006). With these approaches, trenches are filled with wood chips or other organic materials to create a "bioreactor" where enhanced denitrification can occur. If properly positioned to intercept ground or surface water, the denitrification within curtain or filters can remove substantial amounts of nitrate before the water flows into the ditch.
Two different carbon-based (woodchip) bioreactor designs have been used to treat agricultural subsurface drainage water: an in-field and an edge-of-field design. The woodchips serve as a carbon source and as a substrate for colonization of bacteria that transform the nitrogen in the water from the nitrate form to nitrogen gas through the microbially mediated process of denitrification.

In Iowa, trenches were dug adjacent to and parallel with the buried pipe of a subsurface drainage system in-field and then filled with woodchips and covered with soil permitting them to be farmed over (Jaynes et al. 2004). As water passes through the bioreactor filter wall, nitrate in the water is removed before it enters the drain pipe. Researchers at the University of Illinois have been characterizing the performance and the development of design standards for edge-of-field bioreactors (Cooke et al. 2001). In these bioreactor systems, the woodchip layer extends all the way to the surface. The system includes two water-level control structures, a diversion structure that is used to control the volume of water that is diverted through the bioreactor, and a capacity control structure that controls the residence time of water in the bioreactor.

Bioreactors are emerging as a potential best management practice for reducing nitrogen loads from tile drained fields. They are attractive drainage water management practices because current subsurface drainage systems can be easily retrofitted to incorporate bioreactors, minimal crop land is taken out of production, they can be designed to minimize any decrease in drainage system effectiveness, and they require little maintenance. More research is necessary to investigate any potential unintended consequences of bioreactors. Questions exist for example about the rate and amount of greenhouse gas emissions and the production and export of methyl mercury from bioreactors.

For phosphorus, a variety of filtration approaches have been proposed, although fewer have been tested. Penn et al. (2007) describe factors affecting the performance of treatment structures for open ditches, highlighting optimal properties of the phosphorus sorption (binding) material 
and the method in which the barrier is constructed. They describe three general approaches: (a) in-field treatment of soils or applied materials, (b) edge-of-field barriers, and (c) in-line (ditch, tile) filters. In one study evaluating reactive barriers for phosphorus, McDowell et al. (2008) demonstrated that backfilling around tile drains with a slag mixture at time of installation decreased phosphorus discharge from the lines by two-thirds compared with conventionally installed drains. The effective life of the slag system was estimated to exceed 25 years. Hydraulic properties of phosphorus sorbing materials, retention time, and cost present the greatest hurdles to these filters.

\section{AGRONOMIC MANAGEMENT}

From the standpoint of managing water quality, the performance of drainage systems hinges upon prudent agronomic management that precludes mobilization of pollutants by drainage waters. Drainage water management must be considered part and parcel of agronomic management. Most aspects of agronomic management impact the diffuse transfer of nutrients, sediment, and other pollutants to drainage systems. Nutrient management, irrigation management, tillage, crop rotations (e.g., inclusion of perennial and cover crops), and pest management all play a role. The most important first step towards improving water quality is to aid producers in comprehending the link between agronomic practices and drainage water quality. Practices such as cover cropping may appear benign or even unnecessarily costly to a producer until the connection between practice adoption and water quality is made. Alternatively, practices such as no-till may present well-established benefits to surface runoff water quality in one setting but pose concerns to subsurface drainage water quality in another setting (Geohring et al. 2001; Kleinman et al. 2009). Once the link is made, minimizing diffuse transfers of agricultural pollutants requires a constant, conscientious effort that undoubtedly bears some cost to the producer when compared with convention.

\section{CONCLUSIONS}

The concept of precision conservation (which has also been termed target conservation) has been suggested as a way to increase conservation effectiveness by considering spatial and temporal variability when carrying out conservation practices in the field and across the landscape (Berry et al. 2003). Above, we identified a number of practices that could be used to reduce the off-site transport of pollutants in drainage water-drainage system design, controlled drainage, drainage ditches, water storage, buffers and vegetative filter strips, side-inlet controls, reactive barriers, and agronomic management. Precision conservation concepts can be used to strategically place these practices across the landscape and around fields to increase the effectiveness of managing drainage flows and hydrology to harvest nutrients (Delgado and Berry 2008).

\section{REFERENCES}

Berry, J.K., J.A. Delgado, R. Khosla, and F.J. Pierce 2003. Precision conservation for environmental sustainability. Journal of Soil and Water Conservation 58(6):332-339.

Castelle, A.J., A.W. Johnson, and C. Conolly. 1994. Wetland and stream buffer size requirements - A review. Journal of Environmental Quality 23:878-882.

Cooke, R.A., A.M. Doheny, and M.C. Hirshi. 2001. Bio-reactors for edge-of-field treatment of tile flow. ASAE Paper No. 01-2018. St. Joseph, MI ASAE.

Crumpton, W.G., D.A. Kovacic, D.L. Hey, and J.A. Kostel. 2008. Potential of Restored and Constructed Wetlands to Reduce Nutrient Export from Agricultural Watersheds in the Corn Belt. In UMRSHNC (Upper Mississippi River Sub-basin Hypoxia Nutrient Committee). Final Report: Gulf Hypoxia and Local Water Quality Concerns Workshop. St. Joseph, MI: ASABE.

Delgado J.A. and J.K. Berry. 2008. Advances in precision conservation. Advances in Agronomy 98:1-44.

Delgado, J.A., M. Shaffer, C. Hu, R. Lavado, J. Cueto-Wong, P. Joosse, D. Sotomayor, W. Colon, R. Follett, S. DelGrosso, X. Li, and H. RimskiKorsakov. 2008. An index approach to assess nitrogen losses to the environment. Ecological Engineering 32:108-120.
Dosskey, M.G. 2001. Toward quantifying water pollution abatement in response to installing buffers on crop land. Journal of Environmental Management 28:577-598.

Evans, R., J.W. Gilliam, and W. Skaggs. 1996 Controlled drainage management guidelines for improving drainage water quality. NC Cooperative Extension Service, Publication AG443. http://www.bae.ncsu.edu/programs/ extension/evans/ag443.html.

Feser, S.E., J.S. Strock, G.R. Sands, and A.S. Birr 2010. Controlled drainage to improve edgeof-field water quality in southwest Minnesota, USA. In Drainage IX: Proceedings of the Ninth International Drainage Symposium, Quebec City, QC, June 13-16, 2010. St. Joseph, MI: ASABE.

Geohring, L.D., O.V. McHugh, M.T. Walter, T.S. Steenhuis, M.S. Akhtar, and M.F. Walter. 2001. Phosphorus transport into subsurface drains by macropores after manure applications: implications for best manure management practices. Soil Science 166:896-909.

Greenan, C.M., T.B. Moorman, T.C. Kaspar, T.B. Parkin, and D.B. Jaynes. 2006. Comparing carbon substrates for denitrification of subsurface drainage water. Journal of Environmental Quality 35:824-829.

Helmers, M.J., T.M. Isenhart, M.G. Dosskey, S.M. Dabney, and J.S. Strock. 2008. Buffers and Vegetative Filter Strips. In UMRSHNC (Upper Mississippi River Sub-basin Hypoxia Nutrient Committee). Final Report: Gulf Hypoxia and Local Water Quality Concerns Workshop. St. Joseph, MI: ASABE.

Jaynes, D.B., T.C. Kaspar, T.B., Moorman, and T.B. Parkin. 2004. Potential methods for reducing nitrate losses in artificially drained fields. pp. 5969 In Drainage VIII. Proceedings of the Eighth International Drainage Symposium, Sacramento, CA, March 21-24, 2004, ed. R. A. Cooke, 59-69. St. Joseph, MI: ASAE.

Jaynes, D.B., T.C.Kaspar, T.B. Moorman, and T.B. Parkin. 2008. In situ bioreactors and deep drain-pipe installation to reduce nitrate losses in artificially drained fields. Journal of Environmental Quality 37:429-436.

Kadlec, R.H. and R.L. Knight. 1996. Treatment Wetlands. Boca Raton, FL: Lewis Publishers.

Kladivko, E.J., G.E. Van Scoyoc, E.J. Monke, K.M. Oates, and W.Pask. 1991. Pesticide and nutrient movement into subsurface tile drains on a silt loam soil in Indiana. Journal of Environmental Quality 20:264-270. 
Kleinman, P.J.A., A.L. Allen, B.A. Needelman, A.N. Sharpley, P.A. Vadas, L.S. Saporito, G.J. Folmar, and R.B. Bryant. 2007. Dynamics of phosphorus transfers from heavily manured coastal plain soils to drainage ditches. Journal of Soil and Water Conservation 62(4):225-235.

Kleinman, P.J.A., A.N. Sharpley, L.S. Saporito, A.R. Buda, and R.B. Bryant. 2009. Application of manure to no-till soils: Phosphorus losses by subsurface and surface pathways. Nutrient Cycling in Agroecosystems 84:215-227.

Lalonde, V., C.A. Madramootoo, L. Trenholm, and R.S. Broughton. 1996. Effects of controlled drainage on nitrate concentrations in subsurface drain discharge. Agricultural Water Management 29:187-199.

Madramootoo, C.A., W.R. Johnston, J.E. Ayars, R.O. Evans, and N.R. Fausey. 2007. Agricultural drainage management, quality and disposal issues in North America. Irrigation and Drainage 56: S35-S45.

McCarty, G.W., and J.C. Ritchie. 2002. Impact of soil movement on carbon sequestration in agricultural ecosystems. Environmental Pollution 116:423-430.

McDowell, R.W., A.N. Sharpley, and W. Bourke. 2008. Treatment of drainage water with industrial by-products to prevent phosphorus loss from tiledrained land. Journal of Environmental Quality 37:1575-1582.

Needelman, B.A., P.J.A. Kleinman, A.L. Allen and J.S. Strock. 2007. Managing agricultural drainage ditches for water quality protection. Journal of Soil and Water Conservation 62(4): 171-178.

Nistor, A.P., and J. Lowenberg-DeBoer. 2007. Drainage water management impact on farm profitability. Journal of Soil and Water Conservation 62(6):443-446.

Osborne, L.L., and D.A. Kovacic. 1993. Riparian vegetated buffer strips in water-quality restoration and stream management. Freshwater Biology 29: 243-258.

Pappas, E.A., and D.R. Smith. 2007. Effects of dredging and agricultural drainage ditch on water column herbicide concentration, as predicted by fluvarium techniques. Journal of Soil and Water Conservation 62(4):262-268.

Penn, C.J., R.B. Bryant, P.J.A. Kleinman and A.L. Allen. 2007. Sequestering dissolved phosphorus from ditch drainage water. Journal of Soil and Water Conservation 62(4):269-276.

Powell, G.E., A.D.Ward, D.E. Mecklenburg, J. Draper, and W. Word. 2007. Two-stage channel systems: Part 2, case studies. Journal of Soil and Water Conservation 62(4):286-296.
Riley, K.D., M.J. Helmers, P.A. Lawlor, and R. Singh. 2009. Water balance investigation of drainage water management in non-weighing lysimeters. Applied Engineering in Agriculture 25:507-513.

Sands, G.R., I. Song, L.M. Busman, B. Hansen. 2008. The Effects of subsurface drainage depth and intensity on nitrate load in a cold climate. Transactions of the ASABE 51:937-946.

Sharpley,A.N.,J.L.Weld, D.B. Beegle, P.J.A. Kleinman, W.J. Gburek, P.A. Moore, Jr. and G. Mullins. 2003. Development of phosphorus indices for nutrient management planning strategies in the United States. Journal of Soil and Water Conservation 58(3):137-152.

Shigaki, F., P.J.A. Kleinman, J.P. Schmidt, A.N. Sharpley and A.L.Allen. 2008. Impact of dredging on phosphorus transport in agricultural drainage ditches of the Atlantic Coastal Plain. Journal of the American Water Resources Association 44:1500-1511.

Skaggs, R.W., M.A. Youssef, and R.O. Evans. 2005. Agricultural drainage management effects on water conservation, $\mathrm{N}$ loss and crop yields. P. 41. In Proceedings of 2nd Agricultural Drainage and Water Quality Field Day, August 19, 2005. Lamberton, MN: University of Minnesota.

Smith, D.R. and E.A. Pappas. 2007. Effect of ditch dredging on the fate of nutrients in deep drainage ditches of the Midwestern United States. Journal of Soil and Water Conservation 62(4):252-261.

Strock, J.S., J.P. Schmidt, and C. Dell. 2007. Managing natural processes in drainage ditches for nonpoint source nitrogen control. Journal of Soil and Water Conservation 62(4):188-196.

Tan, C.S., C.F. Drury, M. Soultani, I.J. van Wesenbeeck, H.F.Y. Ng, J.D. Gaynor, and T.W. Welacky. 1998. Effect of controlled drainage and tillage on soil structure and tile drainage nitrate loss at the field scale. Water Science and Technology 38:103-110.

USDA NRCS (Natural Resources Conservation Service). 2010. Conservation Practice Standards. USDA NRCS. http://www.nrcs.usda. gov/technical/efotg/. 